\title{
Sequence Analysis of Bacterial DNA in the Colon and Stomach of the
}

Tyrolean Iceman

Raul J. Cano, ${ }^{1}$ Friedrich Tiefenbrunner, ${ }^{2}$ Massimo Ubaldi, ${ }^{3}$ Clarissa Del Cueto, ${ }^{4}$ Stefania Luciani, ${ }^{3}$ Tobe Cox, ${ }^{1}$ Paula Orkand, ${ }^{4}$ Karl H. Kunzel,,${ }^{5}$ and Franco Rollo ${ }^{3 *}$

${ }^{1}$ Environmental Biotechnology Institute,California Polytechnic State University, San Luis Obispo, California 93407

${ }^{2}$ Hygiene Institute, University of Innsbruck, A-6020 Innsbruck, Austria

${ }^{3}$ Dipartimento di Biologia Molecolare, Cellulare e Animale, Universita`di Camerino, 62032 Camerino, Italy

${ }^{4}$ Instituto de Neurobiologi 'a, Universidad de Puerto Rico, San Juan, Puerto Rico 00901

${ }^{5}$ Institute of Anatomy, University of Innsbruck, A-6010 Innsbruck, Austria

ABSTRACT The male human body found in an Alpine glacier on September 19, 1991 (“Tyrolean Iceman”) has, for the first time in history, given scientists a chance to perform detailed anatomical, histological, and molecular investigations on the organs of a person from the Neolithic Age (5350- 5100 B.P.). In the present study, tissue samples aseptically taken from the stomach and the colon of the mummy were utilized for DNA extraction, and the DNA was PCR-amplified, using primer pairs designed to bind to fragments of the 16s ribosomal RNA gene (16s rDNA) of a broad range of bacteria. The PCR products were cloned in plasmid vectors, and the recombinant clones (amplicons) were sequenced. The sequence data were finally used for scanning data libraries containing the corresponding sequences of present-day bacteria, to infer the putative ecophysiology of the ancient ones. The same procedure was repeated on some fragments of grass from the clothing found near the corpse. These fragments were taken as a control of the microbiological situation of the glacier. The results show that the flora of the Iceman's stomach is entirely composed of Burkholderia pickettii, an organism commonly found in aquatic habitats. The colon, on the other hand, contains several members of the fecal flora of humans, 
such as Clostridium perfringens, C. ghonii, C. sordellii, Eubacterium tenue, and Bacteroides sp. The Iceman's colon, however, was found to contain, rather unexpectedly, also some members of the genus Vibrio. The results are discussed in light of what is known about the preservation of microbial DNA at the Iceman's site and of previous parasitological studies performed on the Iceman himself and on human coprolites. Am J Phys Anthropol 112:297-309, 2000.

One of the most exciting archaeological discoveries of the century has been the mummified corpse of a prehistoric man, known as the "Tyrolean Iceman" or "Otzi” on September 19, 1991. It was found at 3,213 $\mathrm{m}$ above sea level near the Similaun glacier, in the Otztaler Alps, close to the Austro-Italian border. Radiocarbon datings indicated an age between 5,350 and 5,100 years (Bonani et al., 1992) corresponding to the Late Neolithic. After a long stay at the Innsbruck University Anatomy Institute (Austria), lasting about 7 years, the mummy is now preserved and exhibited at the Archaeological Museum of Bolzano (Italy).

Together with the body, a full set of surviving tools and weapons were found, including an ax made of a wooden haft and copper blade, a bow-stave with arrows, and a small dagger made of flint. A whole Neolithic garment was also recovered at the Alpine archaeological site. It included a cloak made of knotted tufts of grass, and footwear made of leather, which employed hay as stuffing (Spindler, 1995). The major recovery of remains was performed a few days after the discovery and without special precaution. One year later, a second archaeological expedition allowed a further acquisition of interesting finds comprising uncontaminated grass and leather fragments from the clothing and uncontaminated skin fragments from the body (Bagolini et al., 1995).

In a previous investigation (Ubaldi et al., 1998), we analyzed the distribution of bacterial 
DNA in different organs and tissues of a Peruvian mummy and showed that it was possible to identify the major bacterial taxa in the intestinal microflora of a person who lived in the Andes about 1,000 years ago. The bacterial flora of the intestinal ecosystem is known to be influenced by diet, interaction among microorganisms, drug assumption, toxins, and carcinogenic substances (Blaut et al., 1998).

The present study describes the analysis of bacterial DNA in tissue samples obtained aseptically from the stomach and colon of the glacier mummy. The same analysis was performed on some fragments of grass clothing taken as a control of the microbiological situation of the glacier where the mummy was found.

\section{MATERIALS AND METHODS}

\section{Collection of samples}

Grass samples. Small fragments of grass (each about $4 \mathrm{~cm}$ in length, equivalent to approximately $16 \mathrm{mg}$ dry weight) were taken from three samples (T27, T44, and T182) collected during the second archaeological expedition, carried out in August 1992 (Rollo

et al., 1994). Soon after their recovery from the ice, the samples were put in a refrigerated container and transferred to Bolzano, where they were kept in a freezer at $-5^{\circ} \mathrm{C}$ to $2^{\circ} \mathrm{C}$. The following month, the samples of grass were transferred to the Department of Molecular and Cell Biology of the University of Camerino in a thermally insulated container and stored at $-25^{\circ} \mathrm{C}$. Details of the recovery and description of such finds are recorded by Bagolini et al. (1995). Subsequently, the samples were radiocarbon-dated using accelerator mass spectrometry (Rollo et al., 1994) to check the contemporaneity between the mummy and these finds.

Biopsic samples. Colon and stomach tissue samples from the Iceman were collected by 
endoscopic surgery under strict aseptic conditions, using thoroughly sterilized titaniummade, pointed, and blunt trocars, forceps, nippers, and scissors. To avoid any kind of surface contamination, a rectangular portion of the skin was aseptically cut and lifted to insert the titanium trocar tube. The specimens were placed in toxin-free plastic tubes and kept frozen at $-70^{\circ} \mathrm{C}$ until processed for DNA extraction or for electron microscopic studies.

\section{Electron microscopic studies}

Representative samples of biopsies from the colon were fixed in $2 \%$ glutaraldehyde, $\mathrm{pH}$ 7.0, for $24 \mathrm{hr}$ and washed in $0.1 \mathrm{M}$ cacodylate buffer. Post-fixation was carried out with $1 \%$ OsO4 in $0.1 \mathrm{M}$ cacodylate buffer for $24 \mathrm{hr}$, dehydrated in an alcohol series, stained en bloc with 3\% uranyl acetate, and mounted in epoxy. After the resin hardened, $1-\mu \mathrm{m}$ sections were cut, and microscopic examination was performed.

\section{Aspartic acid racemization}

Aspartic acid (Asp) racemization studies were performed on small representative fragments of the colon and stomach (about 10-15 mg each) as described by Poinar et al. (1996). Briefly, the specimens were washed in $\mathrm{HCl} 0.01 \mathrm{~N}$ and hydrolyzed in twice-distilled $6 \mathrm{~N} \mathrm{HCl}$ for $24 \mathrm{hr}$ at $100^{\circ} \mathrm{C}$. The hydrolysates were desiccated under vacuum and the residues were reconstituted in twice-distilled water. The amino acids were derivatized with O-phthaldialdehyde/Nacetyl-L-cysteine (OPA/NAC) and analyzed by a high-pressure liquid chromatography (HPLC) system (HP 1100, Hewlett Packard, Palo Alto, CA), using fluorescent detection (Zaho and Bada, 1995)

\section{DNA analysis}


Extraction and PCR amplification of DNA from grass samples. The details of the DNA extraction procedure from grass samples (T27, T44, and T182) were reported in Rollo et al. (1995a). The DNA, finally precipitated using ethanol at $-20^{\circ} \mathrm{C}$, was further purified by gel electrophoresis on $1.5 \%$ low melting temperature agarose to eliminate PCR inhibitors. The electrophoretic fractionation showed that the DNA separates in a main band corresponding to approximately $20 \mathrm{~kb}$ in length, preceded by a long smear of fragments down to 100-200 bp in length (Rollo et al., 1995a). For PCR amplification, the agarose was cut in correspondence with the $100-5,000$-bp fraction of the fluorescent smear and melted at $65^{\circ} \mathrm{C}$, and $1 \mu \mathrm{l}$ of the agarose-DNA suspension was directly added to the reaction mixture.

Enzymatic amplifications were performed in $50 \mu \mathrm{l}$ of a reaction mixture containing $10 \mathrm{mM}$ Tris-HCl, pH 8.3, $1.5 \mathrm{mM} \mathrm{MgCl2,} 50 \mathrm{mM} \mathrm{KCl,} 0.1 \mathrm{mg} / \mathrm{ml}$ gelatin, $200 \mathrm{mM}$ of each dNTP, 1 $\mathrm{mM}$ of each oligonucleotide primer, and 2.5 units of Taq polymerase (AmpliTaqTM, Perkin Elmer Cetus). Combinations of universal oligonucleotide primers designed to bind to relatively long (500-800 bp) portions of the 16s rDNA (see below) were unsuccessful; therefore, the following universal oligonucleotide primers of Lane (1991) were employed: 27F, 5'-AGAGTTTGATCCTGGCTCAG-3'; and 342R, 5'-CT-GCTGCCTCCCGTAG-3'. These primers bind to an approximately 350-bp-long portion of the bacterial gene for $16 \mathrm{~s}$ ribosomal RNA (16s rDNA). The short length of the fragment ensures a high amplification efficiency. Following an initial step at $94^{\circ} \mathrm{C}$ for 5 min to denature genomic DNA, the thermal cycler was set at $94^{\circ} \mathrm{C}$ for $1 \mathrm{~min}, 58^{\circ} \mathrm{C}$ for $30 \mathrm{sec}$, and $72^{\circ} \mathrm{C}$ for $1 \mathrm{~min}$. Forty-five amplification cycles were performed.

Extraction and PCR amplification of DNA from biopsic samples. Endoscopic biopsy specimens from the colon or stomach were pulverized in a sterile Braun glass homogenizer. 
DNA extraction was performed as described by Cano (1997) on the basis of Boom et al. (1990). Amplifications were performed as described by Cano (1997), using $5 \mu \mathrm{l}$ of extracted DNA, 2 units of low DNA AmpliTaq DNA polymerase (Perkin-Elmer, Norwalk, CT), $2 \mu \mathrm{g} / \mathrm{ml}$ bovine serum albumin, $0.5 \mu \mathrm{M}$ each of a pair of 16s rDNA forward and reverse primers, $2.0 \mathrm{mM} \mathrm{MgCl}$, and $200 \mathrm{mM}$ of each dNTP in a total volume of $50 \mu \mathrm{l}$. The following primers were employed: 8F, 5'-AGCGTCAAACTTTTAAATTGAA-3'; 564R, 5'-CCTGCGTGCGCTTTACGCCC-3'; 584R, 5'-ACATCTGACTTAACAAACCG-3'; and 805R, 5'-TCGACATCGTTTACGGCGTG-3'. Each primer was coded with a number indicating the position of the 5' base using E. coli 16s rRNA nucleotide position numbering. The following primer combinations were used: 8F-564R, 8F-584R, and 8F-805R, spanning, respectively, DNA segments of 556, 576, and 797 bp of length.

For the primer pair 8F-805R, PCR consisted of an initial denaturation step at $94^{\circ} \mathrm{C}$ for 2 min followed by 40 cycles of denaturation at $94^{\circ} \mathrm{C}$ for $30 \mathrm{sec}$, annealing at $58^{\circ} \mathrm{C}$ for $30 \mathrm{sec}$, and elongation at $72^{\circ} \mathrm{C}$ for 1 min.

For the primer pairs 8F-584R and 8F-564R, the amplifications were carried out for 35 cycles of $94^{\circ} \mathrm{C}$ for $30 \mathrm{sec}, 57^{\circ} \mathrm{C}$ for $30 \mathrm{sec}$, and $72^{\circ} \mathrm{C}$ for $45 \mathrm{sec}$. The amplifications were initiated by 2 min at $94^{\circ} \mathrm{C}$ to denature genomic DNA.

To assess the presence of inhibitors of the PCR in DNA samples from extracted tissues, aliquots of extracted DNA were seeded with approximately 1 pg of plasmid DNA containing a 440-bp fragment of $E$. coli and enzymatically amplified using the appropriate primers and amplification conditions. Amplified DNA was evaluated by gel electrophoresis.

In the amplifications both of purified grass DNA and of DNA extracted from biopsic 
samples, to eliminate small amounts of $E$. coli DNA possibly present in the commercial enzyme preparations and, in general, any types of contaminant DNA, the Taq polymerase and reaction components were pretreated with 3 units of DNase I (from bovine pancreas) for 30 min at room temperature. After incubation, the DNase I was inactivated by boiling for 10 $\min$ at $94^{\circ} \mathrm{C}$.

DNA cloning and sequencing. Amplification products were cloned into pMOS-Blue T-vector (pMOS-Blue T-vector kit, Amer-sham, UK) according to the manufacturer's instructions. Recombinant plasmids were isolated by silica gel procedure (Plasmix, Talent, Trieste, Italy). The purified products were cycle sequenced using dye-deoxy terminators and M13 lacZ forward and reverse primers. We utilized either an ABI PRISM 310 or an ABI PRISM 377 automated sequencer (dRhodamine Terminator Cycle Sequencing Ready Reaction, PE Applied Biosystems, Foster City, CA). The nucleotide sequence of the shortest (350 bp) grass inserts was read in one direction, while that of the longest inserts from the stomach and colon was read in two directions.

Phylogenetic analyses. Sequences were initially compared with reference sequences available in the databases of Genbank and EMBL by using ungapped BLAST (Altschul et al., 1990) and FASTA (Pearson and Lipman, 1988) search programs to determine their approximate phylogenetic affiliation. In addition, the nucleotide sequences of the amplicons were evaluated for the presence of DNA chimeras by using the CHECKCHIMERA program (Maidak et al., 1997) available from the Ribosomal Database Project. The 16s rDNA sequences were aligned by using the Clustal V function (Higgins et al., 1992) of the GDE 2.0 software package. Distance matrices were constructed from the aligned sequences and corrected for the superimposed mutations by the method of Tajima 
and Nei (1984). Phylogenetic trees were constructed using the TREECON program (Van de Peer and De Wachter, 1993) with a neighbor-joining algorithm (Saitou and Nei, 1987). The robustness of inferred topologies was tested by bootstrap resampling of trees (Felsenstein, 1985).

\section{Precautions to avoid contamination.}

All the extraction and amplification operations were carried out taking into account the precautions required for the analysis of DNA in ancient specimens (Herrmann and Hummel, 1994). These precautions included the wearing of sterile gloves, the pretreatment of mortars, pestles, and homogenizers with $\mathrm{HCl}$, the use of an ultraviolet-irradiated safety cabinet, and dedicated gel tray and tanks. Additionally, mock extraction and blank amplification reactions were always performed. Moreover, it should be pointed out that the use of cloning to identify the composition of PCR products is an efficient strategy to recognize contaminant sequences as well.

The effectiveness of the precautions adopted is shown by the fact that despite all the cloning work in our laboratory being performed using E. coli as a recipient organism, not a single sequence attributable to this bacterium was found in several hundreds of $16 \mathrm{~s}$ rDNA amplicons screened in the course of the present and other ancient DNA investigations.

\section{RESULTS}

\section{Analysis of bacterial DNA from the}

Iceman's gastrointestinal tract

Transmission electron photomicrographs of the colon tissue show the presence of a still 
identifiable muscularis-mucosa (Fig. 1a) and various types of rod-shaped and filamentous bacteria colonizing the surfaces of the colon epithelium (Fig. 1b). In addition, estimates of aspartic acid racemization performed on colon and stomach samples indicated ${ }_{\mathrm{D} / \mathrm{LAsp}}$ ratios ranging from $0.06-0.08$. These values are consistent with a satisfactory degree of DNA preservation (Poinar et al., 1996).

\section{[Insert Figure 1]}

Four out of seven stomach and colon biopsy samples yielded amplifiable DNA. The DNA fragments were successfully cloned into a plasmid vector. A total of 33 clones was analyzed by sequencing: 16 from the stomach library, and the remaining 17 clones from the colon library. The screening of the 16s rDNA library from stomach showed that it was entirely composed of Burkholderia pickettii. Fourteen out of 16 clones analyzed had high percent base identity (=98\%) with either Burkholderia pickettii or its synonym, Pseudomonas pickettii. This organism is commonly found in aquatic habitats and has been isolated from wet hospital equipment, disinfecting solutions, cosmetics, paper mill effluents, teething rings, and a variety of patient sources (McNeil et al., 1985).

On the other hand, the sequence analysis of the colon amplicons showed a mixture of bacterial species (Table 1). The most representative species is C. perfringens (clones O8SB, O8SC, O8SG, O8SH, 1A, Oim29, and Oim26), an anaerobic, Gram-positive, sporeforming rod, widely distributed in the environment. This species of Clostridium is frequently part of the normal human endogenous flora and is commonly isolated from infections in humans (Lewis et al., 1980). The molecular analysis also led to the identification of some more clostridia: C. ghonii (clone O8SA) that can be isolated from soil, marine sediments, soft-tissue infections in humans (Gorbach and Thadepalli, 1975), 
and human feces (Finegold et al., 1983), and C. sordelli (O8SD). The latter is an organism normally isolated from soil, normal human feces, and human clinical specimens (Gorbach and Thadepalli, 1975).

The 16s rDNA sequence of the clones O8SE and O815 show a correlation with Eubacterium tenue, which can be isolated from abscesses following abortion, knee synovial fluid, blood, and fecal samples.

Bacteroides sp. (clone OI1675) was also detected in the Iceman's gut. This bacterium is a prominent member of the human gut flora (Hill, 1995) and is commonly encountered in clinical specimens from the gastrointestinal tract (Isenberg and D’Amato, 1991).

A member of the genus Bacillus (clone I110) was also identified. The natural habitat of Bacillus spp. is the soil, but strains of this genus have also been isolated from samples in extreme environments such as deserts and Antarctica. This sporing aerobe is also a member of the normal fecal flora of healthy adult humans, with a reported concentration of $10^{4}-10^{6}$ cells per gram of feces (Hill, 1995).

It is noteworthy that members of the genus Vibrio (clones Oim25, OIm30, and OIm31) were detected in relatively high numbers. These are facultative anaerobic, asporigenous, Gram-negative rods that are natural inhabitants of aquatic environments. Infections of the colon are contracted by the fecal-oral route (Kelly et al., 1991).

Two clones (Oim 25 and Oim30) most closely resemble Vibrio metschnikovii. This organism is one of the species of Vibrio that can be found in human clinical specimens. Although not a bona fide human pathogen, V. metschnikovii has been reported to cause human diarrhea (Dalsgaard et al., 1996; Buck, 1992; Magalhaes et al., 1996). Furthermore, $V$. metschnikovii has been isolated from lakes and streams with evidence of fecal 
contamination (Dalsgaard et al., 1996; Bitto et al., 1992).

[Insert Table 1]

\section{Analysis of bacterial DNA from the}

\section{Iceman's grass clothing}

Of the three specimens tested, only one (T27) produced a weak band of amplified DNA. The amplification product was subsequently cloned into a plasmid vector to produce a library of amplicons. Thirty amplicons from the library were analyzed by sequencing. The results of the comparison with the reference sequences in the database are shown in Table 2.

The bacterial DNA associated with the Neolithic grass shows a considerable degree of heterogeneity in species composition. The nucleotide sequences obtained from five clones (T2721a, T2702a, T2705b, T2778c, and T2784c) appear to be closely related to the organisms of the genus Duganella, formerly called Zoogloea (Hiraishi et al., 1997). Such microrganisms (P-proteobacteria) include Gram-negative aerobic rods, and as porigenous and noncyst-forming eubacteria. The species of the genus Duganella are found principally in organically polluted fresh waters, wastewaters, and aerobic biological wastewater treatment systems. They are also commonly found in drinking-water biofilms (Kalmbach et al., 1997). A recent work describes the organisms of this genus as recurring contaminants during PCR analysis (Tanner et al., 1998).

Clostridium spp. (clones T2707a, T2703c, T2703b, and T27118c) are relatively abundant among the Iceman's grass microflora, reflecting their wide distribution over the earth’s environments. They are commonly found in soil, sewage, marine sediments, decaying vegetation, and animal and plant products. In addition, they can be isolated from 
the intestinal tract of mammals, other vertebrates, and insects, and from wounds or softtissue infections of humans and other animals.

The clone T2789c shows considerable sequence similarity with an unidentified aproteobacterium found during the investigation of an indigenous bacterial community in marine Antarctic ice characterized by psycrophilic and gas-vacuolated members (Gosink and Staley, 1995). Other clones (T2704b, T2715a, and T2760c) show sequence similarity with bacteria of the genus Arthrobacter. Bacteria of this genus are important members of soil communities. Although they do not produce spores, they are remarkably resistant to desiccation (Stolp, 1988). Psychrophilic strains have been found in cave and glacier muds in the Arctic, Lapland, the Pyrenees, and the Alps (Gounot, 1967; Cameron et al., 1973) and in lacustrine environments.

[Insert Table 2]

Among the sequences of organisms at present available in the nucleotide databases, the group of clones T2702b, T2719c, and T2767c shows a certain grade of similarity with an unidentified Cytophagales bacterium (D84607) isolated from environmental samples (Mitsui et al., 1997). This organism is also considered a laboratory contaminant of PCR processes (Tanner et al., 1998).

Agrococcus jenensis (clone T2704c) is a Gram-positive coryneform bacterium isolated from soil and from sandstone layers.

The nucleotide sequence of clone T2727a shows some similarity with the corresponding sequence of Deinococcus radiodurans. Several observations suggest that Deinococcus species may be widely distributed in nature, but in modest number. They can be isolated from many sites, including the air of clean rooms and laboratories (Murray and Brooks, 
1986). On the other hand, T2703a and T2727c sequences seem to be related to that of Curtobacterium citreum. The Curtobacteria are irregular, nonsporing, Gram-positive rods and are obligately aerobic; most members of the genus have been isolated from plants (Komagata and Suzuki, 1986).

The clones T2704c, T2757c, and T2730c show a moderate similarity with the corresponding sequences of species of the genus Pseudomonas isolated from Arctic soil polluted with fossil fuel. Psycrophilic members of this genus have been reported in caves of Lapponia, the Pyrenees, and the Alps (Baross and Morita, 1978). Finally, the nucleotide sequences of a group of amplicons (T2772c, T2705a, T2715c, T2785c, T2724c, T2794c, and $\mathrm{T} 27107 \mathrm{c}$ ) prove to be correlated with the corresponding sequences of microorganisms identified in very different environmental samples by a culture-independent molecular phylogenetic approach (Suzuki et al., 1997; Dojka et al., 1998).

\section{DISCUSSION AND CONCLUSIONS}

The first analyses of the mummy's endogenous DNA performed by Handt et al. (1994) showed that the degradation of the mitochondrial DNA (mtDNA) did not allow the amplification by PCR of molecules longer than 200 base pairs (bp). Besides, the titration of residual human mtDNA molecules, by competitive PCR tests, revealed that the copy number was more than six orders of magnitude less than would be expected in a fresh human tissue. These results led to the conclusion that most of the endogenous DNA was degraded and that single-copy genes could not be amplified from the sample analyzed. Molecular analyses performed on radiocarbon-dated samples of grass coming from the cloak and the stuffing of the footwear, on the other hand, demonstrated that the original DNA of the grass (Rollo et al., 1994) was also maintained. In this case, however, 
fragments of the chloroplast's large subunit of the ribulose bisphosphate carboxylase (rbcL) gene, as long as $530 \mathrm{bp}$, could be retrieved and their nucleotide sequence read. The phylogenetic analysis allowed the plant species utilized by Neolithic man to manufacture his equipment to be identified. In addition, scanning electron microscope observations revealed that the ancient grass was covered by fungal hyphae and algal cysts. The observations also showed very rare bacterial cells. These microorganisms were probably associated with the grass since the Iceman's time (Rollo et al., 1994, 1995a,b).

A more detailed picture, focused on the fungal component of the Iceman's grass clothes, was subsequently produced by Rollo et al. (1995c). The DNA extracted from two radiocarbon-dated specimens was submitted to PCR amplification, employing two different primer pairs. While the first encompassed the nuclear gene for 5.8s ribosomal RNA (rRNA) and flanked transcribed spacers ITS1 and ITS2 (approximately 540 bp in length), the second bound to an approximately 600-bp-long fragment within the reading frame of the nuclear small subunit (SSU) rRNA gene. Amplified DNA was cloned and sequenced. Phylogenetic analyses based on the nucleotide sequences showed that DNAs should be ascribed to a psychrophilic basidiomycetous yeast and two ascomycetes.

The present analyses confirm that bacteria are poorly represented among the grassclothing microflora. Only one out of three DNA preparations from the grass was successfully amplified by PCR, producing only a weak band of DNA. This picture of low bacterial biomass is further confirmed by the recovering of nucleotide sequences corresponding to Duganella sp. (formerly Zoogloea) and an unidentified Cytophagales (D84607). These species have been detected in clone libraries from very different lowbiomass habitats. Because the extraction from low-level DNA samples is particularly 
sensitive to potentially contaminating DNA during the PCR process, it has been supposed that these rDNA sequences may be intrinsic contaminants of PCR reactions (Tanner et al., 1998 ). On the other hand, some of the 16s rDNA amplicons from the grass are indicative of a microbial flora (psycrophilic (x-proteobacterium, Pseudomonas, and Arthrobacter), consistent with the environmental characteristics of the Alpine site and with the microflora composition of the Iceman's skin (Rollo et al., 2000).

The situation inside the Iceman's body is completely different. With regard to the ultrastructural preservation of the mummy tissues, our results basically fit with those reported by Hess et al. (1998). These authors, in particular, noted the presence of bacteria in the digestive tract of the Iceman. Our DNA analyses, on the other hand, clearly show that the microorganisms of the stomach and colon are different. In the colon, Gram-positive, anaerobic rods are largely represented, while in the stomach, with the absolute predominance of Burkholderia, only Gram-negative rods are present. This result demonstrates that no appreciable postmortem translocation of bacteria has taken place from organ to organ.

The finding of Burkholderia pickettii in the stomach, however, deserves a few comments. With the exception of Helicobacter pylori, the normal stomach defenses are suf-

ficiently effective so as to render it free of either pathogenic or saprophytic bacteria. Nor is B. pickettii a known common constituent of the normal oral cavity flora. The most plausible explanation is that this organism may have entered the stomach after death as a passenger in postmortem water aspiration. The Iceman body is known to have been at least partially submerged in a pool of meltwater between the time of his discovery and the removal of the body. In addition, there is increasing evidence that the corpse, in the days 
and weeks following the Iceman's death, was submerged in meltwater (Bereuter et al., 1997; Rollo et al., 2000).

\section{[Insert Figure 2]}

\section{[Insert Figure 3]}

When some (Oim29, Oim26, O8SH, O8S G, O8SB, O8SC, O8SE, O815, O8SD, and O8SA) of the amplicon sequences of the colon microflora are inserted in the phylogenetic tree of Clostridia, they cluster into two main groups (Fig. 2): one is closely related to $C$. perfringens, while the other has a closer relationship with C. difficile, C. ghoni, C. sordelli, and E. tenue. It is remarkable that $C$. perfringens is the predominant species among the organisms identified in the colon microflora of the mummy, and that this bacterium is a member of the human normal endogenous flora. C. sordelli, C. ghoni, and E. tenue are also meaningful representatives of the human gut microflora, and are often isolated from human fecal samples. Also, Bacteroides spp. (clone OI 1675) are considered a prominent member of the human gut flora (Hill, 1995).

Finally, of particular interest is the detection of DNA sequences (clones Oim25, Oim30, and Oim31) corresponding to species of the genus Vibrio. As shown in the phylogenetic tree of Figure 3, these sequences fall in the branching of $V$. aestuarianus and $V$. metschnikovii, and at the same time they occupy a phylogenetically distant position from $V$. cholerae, the organism responsible for a severe form of diarrhea in the cholera epidemic. As mentioned in Results, V. metschnikovii has been frequently isolated from fresh, brackish, and marine waters, and humans occasionally become colonized or infected by these sources. 
It is well-known that there is a correlation between the composition of gut microflora and the dietary habits of an individual, and his well-being. The intestinal microflora plays an important role in preventing colonization by pathogens and takes part in numerous metabolic processes useful for maintaining human health (Blaut et al., 1998). Therefore, the analysis of gut bacterial composition may represent an alternative approach to classical ethno-anthropological methods to infer information about the food habits, lifestyle, and health conditions of ancient civilizations, as well as the structure of human microbial ecosystems of the past.

The Neolithic period was characterized by great innovations and changes that deeply influenced human life. First of all, there was a transition from a nomadic way of life to agriculture, breeding domesticated animals, and a higher level of social interaction among the members of the community than in the Paleolithic. Secondly, the life in larger human aggregates increased the spread of diseases by the fecal-oral route, with the concomitant reduction in survival curves of the early Neolithic human popula tion (Cournede et al., 1996). In view of this, the finding of V. metschnikovii DNA may be connected with that of an egg of Trichuris trichura (whipworm) in the sacro-gluteal region of the mummy and the detection of antibodies against this intestinal parasite (Aspo“ck et al., 1996). This, in turn, fits with the report of Bouchet et al. (1995) describing the identification of many wellpreserved helminth eggs, including Trichuris, Capillaria, Fasciola hepatica, and Diphyllobotrium sp. in 12 human coprolites and in 10 sediment samples rich in organic matter form the Neolithic site of Chalain, Jura.

\section{LITERATURE CITED}

Altschul SF, Gish W, Miller W, Myers EW, Lipman DJ. 1990. Basic local alignment search 
tool. J Mol Biol 215:403-410.

Aspo"ck H, Auer H, Picher O. 1996. Trichuris trichiura eggs in the Neolithic glacier mummy from the Alps. Parasitol Today 12:255-256.

Bagolini B, Dal Ri L, Lippert A, Nothdurfter H. 1995. Der Mann im Eis: die Fundbergung 1992 am Tisenjoch, Gem. Schnals, Su“dtirol. In: Spindler K, Rastbichler-Zissernig E, Wilfing H, zur Nedden D, Nothdurfter H, editors. Der Mann im Eis: neue Funde und Ergebnisse. Wien, New York: Springer-Verlag. p 3-22.

Baross JA, Morita RY. 1978. Microbial life at low temperature: ecological aspects. In: Kushner DJ, editor. Microbial life in extreme environments. London, New York, San Francisco: Academic Press. p 10-57.

Bereuter TL, Mikenda W, Reiter C. 1997. Iceman’s mummification-implications from infrared spectroscopical and histological studies. Chem Eur J 7:1032-1038.

Bitto AO, Kale OO, Oduntan SO. 1992. Epidemiological survey of an outbreak of gastroenteritis in a rural community in Oyo State. West Afr J Med 11:34-38.

Blaut M, Griggs C, Collins MD, Welling G, Dore' J, van Loo J, de Vos W. 1998. Quantitative assessment of the human gut flora using a panel of rRNA targeted hybridization probes. In: Gaukel V, Spieß W, editors. Third Karlsruhe Nutrition Symposium. European research towards safer and better food (proceedings part 1: lectures). October 18-20, 1998. Bundesforschungsanstalt fu"r Ema“hrung, Karlsruhe. p 102-109.

Bonani G, Ivy SD, Niklaus TR, Suter M, Housley RA, Bronj CR, van Klinken GJ, Edges REM. 1992. Altersbestimmung von Lilligrammproben der O" tzaler Gletscherleiche mit der Beschleunigermassenapektrometrie methode (AMS). In: Ho“pfel F, Platzer W, Spindler K, editors. Der Mann im Eis, volume 1. Innsbruck: Vero“ffentlichungen der Universita“t Inns- 
bruck. p. 108-116.

Boom R, Sol C, Salimans M, Jansen C, Wertheim-van Dillen P, van der Noordaa J. 1990. Rapid and simple method for the purification of nucleic acids. J Clin Microbiol 28:495-503.

Bouchet F, Petrequin P, Paicheler JC, Dommelier S. 1995. Premiere approche paleoparasitologique du site neolithique de Chalain Jura, France. Bull Soc Pathol Exot 88:265-268.

Buck JD. 1992. Recovery of Vibrio metschnikovii from Market Seafood. J Food Safety 12:7378.

Cameron RE, Morelli FA, Honour RC. 1973. Aerobiological monitoring of Dry Valley drilling sites. Antarctic J US 8:211-214.

Cano RJ. 1997. DNA amplification techniques in fossilized samples. In: Toranzos GA, editor. Environmental applications of nucleic acid amplification techniques. Lancaster, PA: Technomic Publishing Co. p 183-210.

Cournede N, Designere C, Picouleau D. 1996. Du ne’olithique au 20e`me sie`cle. De la naissance de l'agriculture a` la nutrition the'rapeutique. Soins 604: 85-89.

Dalsgaard A, Alarcon A, Lanata CF, Jensen T, Hansen HJ, Delgado F, Gil AI, Penny ME, Taylor D. 1996. Clinical manifestations and molecular epidemiology of five cases of diarrhoea in children associated with Vibrio metschnikovii in Arequipa, Peru. J Med Microbiol 45:494-500.

Dojka MA, Hugenholtz P, Haack SK, Pace NR. 1998. Microbial diversity in a hydrocarbon- and chlorinated-solvent-contaminated aquifer undergoing intrinsic bioremediation. Appl Environ Microbiol 64:3869-3877.

Felsenstein J. 1985. Confidence limits on phylogenies: an approach using the bootstrap. 
Evolution 39:783-791.

Finegold SM, Sutter VL, Mathisen GE. 1983. Normal indigenous intestinal flora. In: Hentges E, editor. Human intestinal microflora in health and disease. New York: Academic Press. p 331.

Gorbach SL, Thadepalli H. 1975. Isolation of Clostridium in human infections: evaluation of 114 cases. J Infect Dis 131:81-85.

Gosink JJ, Staley JT. 1995. Biodiversity of gas vacuolate bacteria from Antarctic sea ice and water. Appl Environ Microbiol 61:3486-3489.

Gounot AM. 1967. Ro^le biologique des Arthrobacters dans les limons souterrains. Ann Inst Pasteur Paris 113:923-945.

Handt O, Richards M, Trommsdorff M, Kilger C, Simanainen J, Oleg G, Bauer K, Stone A, Hedges R, Schaffner W, Utermann G, Sykes B, Pa“a”bo S. 1994. Molecular genetic analyses of the Tyrolean Ice Man. Science 264:1775-1778.

Herrmann B, Hummel S. 1994. General aspects of sample preparation. In: Hummel S, Herrmann B, editors. Ancient DNA. New York: Springer-Verlag. p 59-68.

Hess MW, Klima G, Pfaller K, Ku“nzel KH, Gaber O. 1998. Histological investigation of the Tyrolean Ice Man. Am J Phys Anthopol 106:521-532.

Higgins DG, Bleasby AJ, Fuchs R. 1992. CLUSTAL V, improved software for multiple sequence alignment. Comput Appl Biosci 8:189-191.

Hill MJ. 1995. The normal gut bacterial flora. In: Hill MJ editor. Role of gut bacteria in human toxicology and pharmacology. London: Taylor and Francis. p 3-17.

Hiraishi A, Shin YK, Sugiyama J. 1997. Proposal to reclassify Zoogloea ramigera IAM 12670 (P. R. Dugan 115) as Duganella zoogloeoides gen. Nov., sp. nov. Int J Syst Bacteriol 
$47: 1249-1252$.

Isenberg HD, D’Amato RF. 1991. Indigenous and pathogenic microorganisms of humans. In: Balows A, Hausler WJ Jr, Herrmann K, Isemberg HD, Shadomy HJ, editors. Manual of clinical microbiology. Washington, DC: ASM Press. p 2-15.

Kalmbach S, Manz W, Szewzyk U. 1997. Isolation of new bacterial species from drinking water biofilms and proof of their in situ dominance with highly specific 16s rRNA probes. Appl Environ Microbiol 63: 4164-4170.

Kelly MT, Hickman-Brenner FW, Farmer JJ III. 1991. Vibrio. In: Balows A, Hausler WJ Jr, Herrmann K, Isemberg HD, Shadomy HJ, editors. Manual of clinical microbiology. Washington, DC: ASM Press. p 384-395.

Komagata K, Suzuki K. 1986. Genus Curtobacterium. In: Holt JG, editor. Bergey’s manual of systematic bacteriology. Baltimore: Williams \& Wilkins. p 1313- 1317.

Lane DJ. 1991. 16s/23s rRNA sequencing. In: Stackebrandt E, Goodfellow M, editors. Nucleic acid techniques in bacterial systematics. Chichester: John Wiley and Sons, Ltd. p $115-175$.

Lewis JF, Mullins N, Johnson P. 1980. Isolation and evaluation of Clostridia from clinical sources. South Med J 73:427-432.

Magalhaes V, Branco A, de Andrade Lima R, Magalhaes M. 1996. Vibrio metschnikovii among diarrheal patients during cholera epidemic in Recife, Brazil. Rev Inst Med Trop Sao Paulo 38:1-3.

Maidak BL, Olsen GJ, Larsen N, Overbeek R, McCaughey M, Woese CR. 1997. The RDP Ribosomal Database Project. Nucleic Acids Res 25:109-111.

McNeil MM, Solomon SL, Anderson RL, Davis BJ, Spengler RF, Reisberg BE, Thornsberry 
C, Martone WJ. 1985. Nosocomial Pseudomonas pickettii colonization associated with a contaminated respiratory therapy solution in a special care nursery. J Clin Microbiol 22:903-907.

Mitsui H, Gorlach K, Lee H, Hattori R, Hattori T. 1997. Incubation time and media requirements of culturable bacteria from different phylogenetic groups. J Microbiol Methods 30:103-110.

Murray RGE, Brooks BW. 1986. Genus I. Deinococcus. In: Holt JG, editor. Bergey’s manual of systematic bacteriology. Baltimore: Williams \& Wilkins. p 1035- 1043.

Pearson WR, Lipman DJ. 1988. Improved tools for biological sequence comparison. Proc Natl Acad Sci USA 85:2444-2448.

Poinar HN, Ho“ss M, Bada JL, Pa“a”bo S. 1996. Amino acid racemization and the preservation of ancient DNA. Science 272:864-866.

Rollo F, Asci W, Antonini S, Marota I, Ubaldi M. 1994. Molecular ecology of a Neolithic meadow: the DNA of the grass remains from the archaeological site of the Tyrolean Iceman. Experientia 50:576-584.

Rollo F, Asci W, Marota I, Sassaroli S. 1995a. DNA analysis of grass remains found at the Iceman’s archaeological site. In: Spindler K, Rastbichler-Zissernig E, Wilfing H, zur Nedden D, Nothdurfter H, editors. Der Mann im Eis: neue Funde und Ergebnisse. Wien, New York: Springer-Verlag. p 91-105.

Rollo F, Asci W, Antonini S, Ubaldi M. 1995b. The "Neolithic" microbial flora of the Iceman’s grass: morphological description and DNA analysis. In: Spindler K, RastbichlerZissernig E, Wilfing H, zur Nedden D, Nothdurfter H, editors. Der Mann im Eis: neue Funde und Ergebnisse. Wien, New York: Springer-Verlag. p 107-114. 
Rollo F, Sassaroli S, Ubaldi M. 1995c. Molecular phylogeny of the fungi of the Iceman's grass clothing. Curr Genet 28:289-297.

Rollo F, Luciani S, Canapa A, Marota I. 2000. Analysis of bacterial DNA in skin and muscle of the Tyrolean Iceman offers new insight into the mummification process. Am J Phys Anthropol 111:211-219.

Saitou N, Nei M. 1987. The neighbor-joining method, a new method for reconstructing phylogenetic trees. Mol Biol Evol 4:406-425.

Spindler K. 1995. The man in the ice. Phoenix, London: Orion Books, Ltd.

Stolp H. 1988. Microbial ecology: organisms, habitats, activities. Cambridge studies in ecology. Cambridge: Cambridge University Press.

Suzuki MT, Rappe MS, Haimberger ZW, Winfield H, Adair N, Strobel J, Giovannoni SJ. 1997. Bacterial diversity among small-subunit rRNA gene clones and cellular isolates from the same seawater sample. Appl Environ Microbiol 63:983-989.

Tajima F, Nei M. 1984. Estimation of evolutionary distance between nucleotide sequences. Mol Biol Evol 1:269-285.

Tanner MA, Goebel BM, Dojka MA, Pace NR. 1998. Specific ribosomal DNA sequences from diverse environmental settings correlate with experimental contaminants. Appl Environ Microbiol 64:3110-3113.

Ubaldi M, Luciani S, Marota I, Fornaciari G, Cano RJ, Rollo F. 1998. Sequence analysis of bacterial DNA in the colon of an Andean mummy. Am J Phys Anthropol 107:285-295.

Van de Peer Y, De Wachter R. 1993. TREECON, a software package for the construction and drawing of evolutionary trees. Comput Appl Biosci 9:177-182.

Zaho M, Bada JL. 1995. Determination of a-dialkylamino acids and their enantiomers in 
geological samples by high-performance liquid chromatography after derivatization with a chiral adduct of o-phthaldaildehyde. J Chromatogr 690:55-63. 


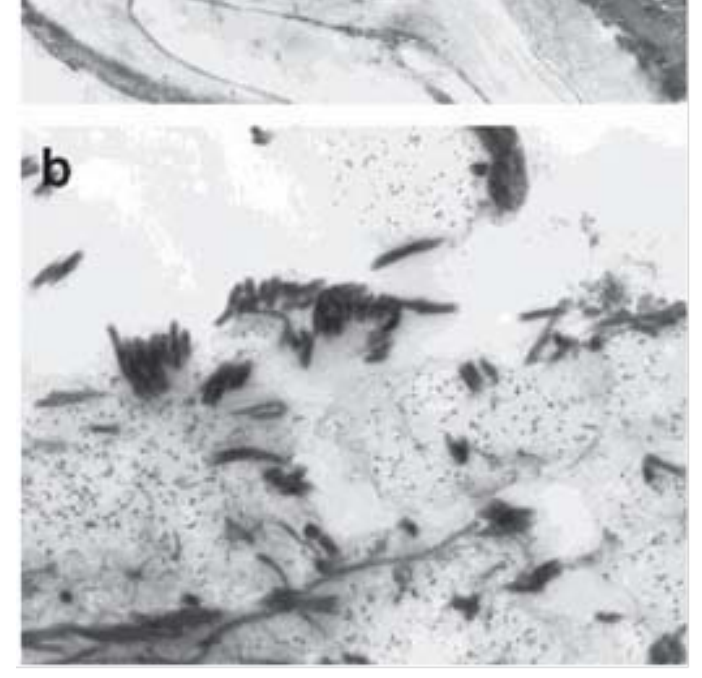

Fig. 1. Transmission electron photomicrographs of colon samples from the Iceman. $\mathbf{a}$ : Cross section of colon, showing muscolaris mucosa; 16,600 X. b : Cross section of colon, showing rod-shaped and filamentous bacteria attached to remnants of the intestinal epithe lium; 36,000 X.

TABLE 1. Characterization of $16 S$ rDNA amplicons from colon

\begin{tabular}{|c|c|c|c|}
\hline $\begin{array}{c}\text { Amplicon } \\
\text { (accession number) }\end{array}$ & Primers & $\begin{array}{l}\text { Closest BLAST identification' } \\
\text { (accession number) }\end{array}$ & $\begin{array}{l}\% \text { nucleotide } \\
\text { identity }\end{array}$ \\
\hline 0815 (AF018087) & $8 \mathrm{~F}-805 \mathrm{R}$ & Eubacterium tenue (M59118) & 97 \\
\hline O8SE (AF018038) & & Eubacterium tenue (M59118) & 97 \\
\hline OBSA (AF018089) & & Clostridium ghonii (X73451) & 97 \\
\hline O8SD (AF018045) & & Clostridium sordellii (M59105) & 95 \\
\hline O8SB (AF018040) & & Clostridium perfringens (M69264) & 96 \\
\hline OBSC (AF018041) & & Clostridium perfringens (M69264) & 99 \\
\hline O8SG (AF018042) & & Clostridium perfringens (M69264) & 99 \\
\hline OBSH (AF018043) & & Clostridium perfringens (M69264) & 99 \\
\hline 1A (AF018044) & $8 \mathrm{~F}-564 \mathrm{R}$ & Clostridium perfringens (M69264) & 98 \\
\hline Oim29 (AF018047) & $8 \mathrm{~F}-584 \mathrm{R}$ & Clostridium perfringens (L34622) & 95 \\
\hline Oim26 (AF018640) & & Clostridium perfringens (L34622) & 95 \\
\hline OI1675 & & Bacteroides sp. (X89217) & 98 \\
\hline I-110 (AF018046) & & Bacillus sp. (D78311) & 97 \\
\hline Oim32 (AF018048) & & Chimera (V. aestuarianus $+C$. difficile) & \\
\hline Oim30 (AF018049) & & Vibrio metschnikovii (X74712) & 98 \\
\hline Oim25 (AF018050) & & Vibrio metschnikovii (X74712) & 92 \\
\hline Oim31 (AF018051) & & Vibrio aestuarianus (X74689) & 94 \\
\hline
\end{tabular}

${ }^{1}$ BLAST search was performed using the full length of the amplicans. 
TABLE 2. Characterization of $16 \mathrm{~S}$ rDNA amplicons from grass clothing

\begin{tabular}{|c|c|c|c|}
\hline $\begin{array}{l}\text { Amplicon } \\
\text { (accession number) }\end{array}$ & Primers & $\begin{array}{l}\text { Closest BLAAST identification' } \\
\text { (accession number) }\end{array}$ & $\begin{array}{l}\% \text { nucleotide } \\
\text { identity }\end{array}$ \\
\hline T2721a (AF018016) & 27F-342R & Uncultured Duganella (AF058387) & 98 \\
\hline T2702a (AF018000) & & Uncultured Duganella (AF058387) & 100 \\
\hline T2705b (AF018008) & & Uncultured Duganella (AF058387) & 93 \\
\hline $\mathrm{T} 2778 \mathrm{c}(\mathrm{AF} 018025)$ & & Uncultured Duganella (AF058387) & 97 \\
\hline T2784c (AF018026) & & Zoogloea ramigera (X74914) & 96 \\
\hline T2703a (AF018002) & & Curtobacterium citreum (X77436) & 92 \\
\hline T2727c (AF018019) & & Curtobacterium citreum (X77436) & 88 \\
\hline T2704b (AF018005) & & Arthrobacter AC-38 (X86594) & 88 \\
\hline T2715a (AF018013) & & Arthrobacter sp. (D84573) & 90 \\
\hline $\mathrm{T} 2760 \mathrm{c}$ (AF018022) & & Arthrobacter sp. (D84573) & 91 \\
\hline T27104c (AF018010) & & Agrococcus jenensis (X92492) & 91 \\
\hline T2703c (AF018004) & & Clostridium tetanomorphum (X66001) & 91 \\
\hline T2707a (AF018009) & & Clostridium pascui (X96736) & 89 \\
\hline T2703b (AF018003) & & Clostridium pascui (X96736) & 88 \\
\hline T27118c (AF018012) & & Clostridium pascui (X96736) & 83 \\
\hline T2727a (AF018018) & & Deinococcus radiodurans (M21413) & 93 \\
\hline T2705a (AF018007) & & Desulfosporosinus sp. (AF076244) & 90 \\
\hline $\mathrm{T} 2704 \mathrm{c}$ (AF018006) & & Pseudomonas sp. (U81871) & 95 \\
\hline T2757c (AF018021) & & Pseudomonas sp. (U81871) & 86 \\
\hline T2730e (AF018020) & & Pseudomonas sp. (U81871) & 84 \\
\hline $\mathrm{T} 2715 \mathrm{c}$ (AF018014) & & Unidentified $\beta$-Proteobacterium (AB011747) & 98 \\
\hline $\mathrm{T} 2724$ (AF018017) & & Unidentified $\beta$-Proteobacterium (AB011747) & 95 \\
\hline $\mathrm{T} 2719 \mathrm{e}$ (AF018015) & & Unidentified Cytophagales bacterium (D84607) & 91 \\
\hline $\mathrm{T} 2767 \mathrm{c}$ (AF018023) & & Unidentified Cytophagales bacterium (D84607) & 86 \\
\hline T2702b (AF018001) & & Unidentified Cytophagales bacterium (D84607) & 89 \\
\hline $\mathrm{T} 2785 \mathrm{c}$ (AF018004) & & Unidentified Eubacterium (AF010007) & 83 \\
\hline T2794c (AF108029) & & Runella slithyformis (X77443) & 96 \\
\hline T2772c (AF018024) & & Uncultured Eubacterium (AF050574) & 97 \\
\hline T27107e (AF018011) & & Marine Bacterium (U78941) & 88 \\
\hline T2789c (AF018028) & & Unidentified $\alpha$-Proteobacterium (U14585) & 95 \\
\hline
\end{tabular}

\footnotetext{
${ }^{1}$ BLAST search was performed using the full length of the amplicons.
} 


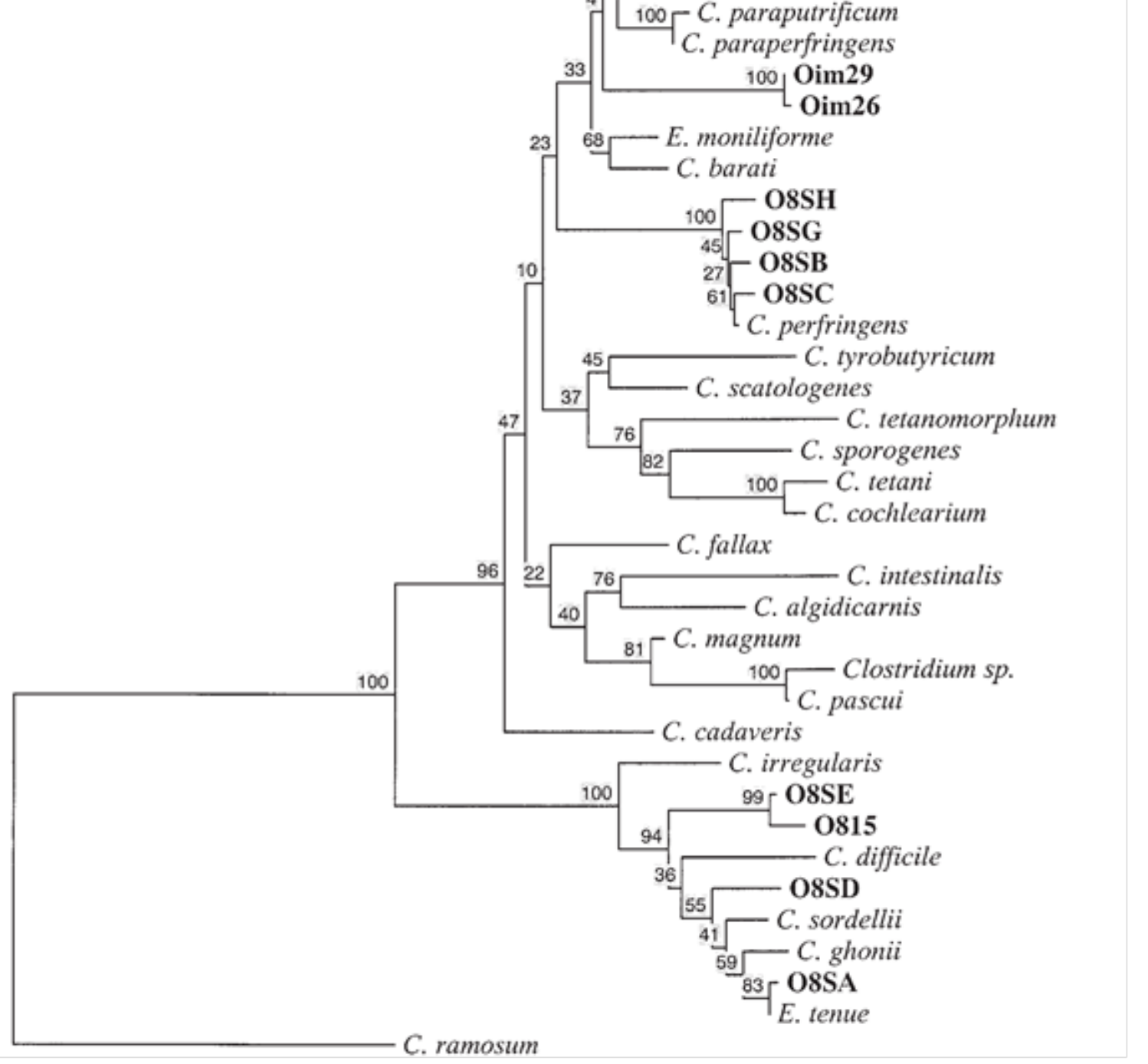

Fig. 2. Phylogenetic tree derived from the analysis of the $16 \mathrm{~s}$ rDNA sequences of the genus Clostridium, inclusive of 10 amplicon sequences from the colon of the Iceman. The tree was constructed using neighbor-joining (Saitou and Nei, 1987) on the basis of a multiple alignment of a portion (about 520 bp) of the 16 s rDNA sequence, and the distances were corrected for super imposed mutations according to Tajima and Nei (1984). The sequence of Clostridium ramosum was used as an outgroup to root the tree. Bootstrap confidence values obtained with 100 resamplings are given at branch points. Scale bar indicates 10 nucleotide substitutions per 100 nucleotides. 


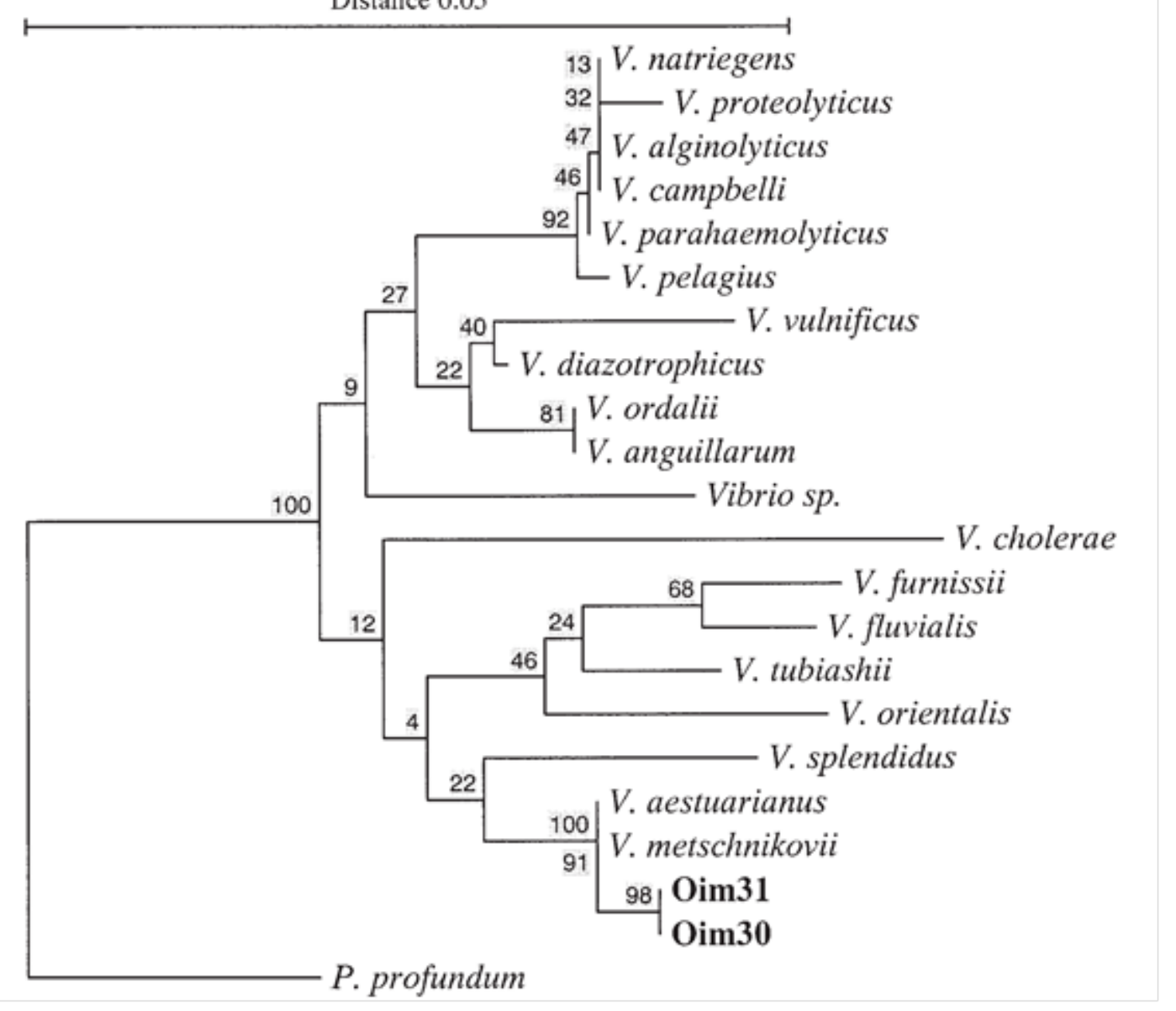

Fig. 3. Phylogenetic tree indicating the position of the Oim30 and Oim31 16s rDNA amplicons from the colon of the Iceman within the Vibrio division. The tree was constructed using neighbor-joining (Saitou and Nei, 1987) on the basis of a multiple alignment of a portion (about $520 \mathrm{bp}$ ) of the $16 \mathrm{~s}$ rDNA sequence, and the distances were corrected for superimposed mutations according to Tajima and Nei (1984). The sequence of Photobacterium profundum was used as an outgroup to root the tree. Bootstrap confidence values obtained with 100 resamplings are given at branch points. Scale bar indicates 5 nucleotide substitutions per 100 nucleotides. 